
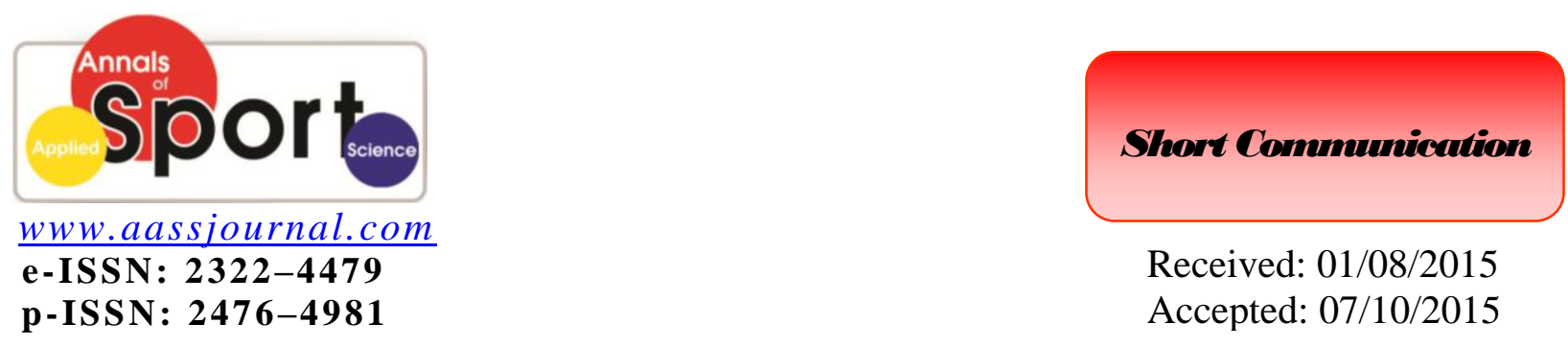

Received: 01/08/2015

Accepted: 07/10/2015

\title{
Examination of Thinking Styles of Trainers from Different Branches
}

\author{
Atalay GACAR*, Oğuzhan ALTUNGÜL, Eyyüp NACAR
}

Department of Physical Education and Sport Science, Firat University, Elazig, Turkey.

\section{BSTRACT}

Thinking styles are a matter of choice in individuals' use of their abilities. In other words, they are processes that determine individuals' attitude towards the problems they encounter and their way of self-expression in the face of these problems. It is considered each athlete and trainer has unique ways in achieving their goals and succeeding. Starting from this, in our study we aim to examine "Thinking Styles of Trainers of Different Branches". 50 trainers, 20 females and 30 males, who coach in different branches in Elazığ city center, participated in our study. In the study, it was used a personal information form to gather participants' demographical information "their gender, being trainer of individual or team sports, year of coaching and educational level" and the REI (Rational Experiential Inventory) developed by Epstein et al. to determine their thinking styles. Consequently, it has been observed the rational and intuitive thinking styles of the trainers from different branches are sufficient in our study. In the light of the findings, it has been concluded that trainers of team sports have high levels of analytical-rational thinking, "participating-not participating in cognitive activities and enjoying-not enjoying cognitive activities", while trainers of individual sports have high levels of intuitive thinking "data processing and trusting-not trusting their feelings and first impressions in their daily life". Our study has importance since it is believed it provides enlightening information for trainers and athletes in their choice of appropriate methods and techniques while performing and coaching and also it forms literature for future studies.

Key Words: Thinking Styles, Trainers, Rational and Intuitive Thinking Styles.

Corresponding Author:

Atalay GACAR

E-mail: gacaratalay@gmail.com 


\section{INTRODUCTION}

We deal with thousands of thoughts while speaking, reading, travelling, and eating in our daily life. Where these thoughts stem from, what they evoke and what we obtain from them differ for each person (1).

Thinking style is defined as the way or method individuals prefer in using their abilities by Sternberg (1995). Thinking style is a choice, not ability. Hence, it cannot be characterized as good or bad. However, we can mention its differences. Therefore, thinking style of individuals may alter depending upon the current situation, problem they handle and also in time (16).

Likewise, two individuals who have similar abilities may differ in their thinking styles. Even though thinking styles are determined by dominance of ability and personality, both notions are related $(12,13,14)$. Thinking style varies by the requirements of the situation. Thinking styles are closely related with social surroundings and may differ based upon culture, time and situation (12).

Thinking styles are a matter of choice in individuals' using their abilities. In other words, they are processes which designate individuals' attitude towards problems and situations they encounter and the way of their self-expression before these problems $(5,13)$.

Psychologists who adopt different approaches have asserted two thinking styles that are different basically but are in interacted with each other (7).

These styles are named with different notions. These are intuitive, experiential, ideational, conceptual-rational and analytical thinking styles $(17,2)$. Each individual develops specific methods and approaches towards his/her relationship with the world, perceiving it, achieving their goals and solving their problems. In that process, individual focuses on various aspects of the truth, gathers all kinds of data, organizes data in different ways and makes different judgmental deduction, reaches different decisions and performs these decisions in different ways $(18,7,3)$.

It is believed each athlete and trainer has unique ways in achieving their goals and succeeding. Based upon this, in our study which is believed to form literature for other studies, it is aimed to examine the thinking styles of the trainers from different branches.

\section{MATERIALS AND METHODS}

Participants. Fifteen trainers, 20 females and 30 males, who coach in different branches in Elazığ city center, participated in our study. 24 of the trainers coach in team sports and 26 of them coach in individual sports.

Tools. In the study, it was used a personal information form to gather participants' demographical information and the REI (Rational Experiential Inventory) developed by Epstein et. al (1996) to determine their thinking styles. Analytical-Rational and Experiential Thinking Styles comprise 31 items and 2 subscales. The first scale contains rational thinking. It comprises abridged 19-item form taken from the Need for Cognition Scale (45-item) developed by Cacioppa and Petty (1982). The scales assess individuals' level of participating-not participating in cognitive activities and enjoying-not enjoying cognitive activities. The second scale is the Faith in Intuition subscale and includes 12 items. The scale measures individuals' level of trusting-not trusting their feelings and first impressions in their daily life behaviors $(4,5)$.

The scale is a 5 point likert scale. Graduation level increases 1 to 5 and responses are given through levels of "Strongly Disagree" to "Strongly Agree". 1st, 2nd, 3rd, 4th, 5th, 6th, 7th, 9th, 10th, 11th, 13th, 15th, 16th, 18th and 19th items of the Need for Cognition subscale are measured reversely and the score interval of 
the scale varies between 19-95. Scoring of the Faith in Intuition subscale is not implemented reversely since the items are stated as positive statements and the score interval varies through 12-60 (5).

Statistical Analysis. Frequency distribution, arithmetic mean, percentages, independent sample t-test and One-Way ANOVA with Tukey posthoc test was used to analyze data. Data was analyzed using SPSS software. A level of 0.05 was considered significant.

\section{RESULTS}

When the value of distribution function of trainers who attended the study was examined in respect to "branch of coaching" variable; it was seen that there were 24 trainers by $\% 48$ participation in team sports and 26 trainers by $\% 52$ participation in individual sports (table 1).

\begin{tabular}{ccc}
\hline Table 1. Distribution of Trainers As To The "Branch of Coaching Variable" \\
\hline Branch of Coaching & N & $\%$ \\
\hline Volleyball & 6 & 10.2 \\
Handball & 5 & 10.0 \\
Futsal & 4 & 0.8 \\
Football & 6 & 10.2 \\
Basketball & 5 & 10.0 \\
Box & 5 & 10.8 \\
Tae Kwon Do & 6 & 10.2 \\
Archery & 2 & 0.4 \\
Kickbox & 4 & 0.8 \\
Wrestling & 2 & 0.4 \\
Judo & 3 & 0.6 \\
Athletics & 2 & 0.4 \\
\hline Total & 50 & 100,0 \\
\hline
\end{tabular}

In Table 2 and 3, when the analysis results in respect to the points of Rational-Experiential Thinking Styles as to gender and year of coaching history variables of trainers on different branches, respectively, were examined, it was found out that there was not significant differentiation in terms of gender and year of coaching history variables, respectively, from the sub-scales of Rational Thinking and Intuitive Thinking factors $(\mathrm{p}<0.05)$.
In Table 4, when the analysis results in respect to the points of team and individual sport trainers' RationalExperiential Thinking Styles on different branches were examined, it was found out that there was significant differentiation in terms of sub-scales of Rational Thinking $(\mathrm{p}>0.001)$ and Intuitive Thinking $(p>0,005)$ factors.

\begin{tabular}{cccccccc}
\hline \multicolumn{1}{c}{ Table 2. Rational-Experiential Thinking Styles Scale as to Gender } \\
\hline REI & GENDER & $\mathbf{N}$ & $\overline{\mathrm{X}}$ & $\mathbf{S s}$ & $\mathbf{t}$ & $\mathbf{p}$ \\
\hline $\begin{array}{c}\text { Analytical-Rational } \\
\text { Thinking }\end{array}$ & Male & 30 & 39.50 & 8.12 & -0.41 & \multirow{2}{*}{0.68} \\
\hline \multirow{2}{*}{ Intuitive Thinking } & Female & 20 & 40.60 & 10.76 & & \\
\hline & Male & 30 & 56.00 & 9.25 & \multirow{2}{*}{-0.15} & 0.87 \\
\hline
\end{tabular}


Table 3. Rational-Experiential Thinking Styles Scale as to Year of Coaching History

\begin{tabular}{ccccccc}
\hline REI & Year of Coaching & $\mathbf{N}$ & $\overline{\mathbf{X}}$ & $\mathbf{S s}$ & $\mathbf{F}$ & $\mathbf{p}$ \\
\hline \multirow{2}{*}{ Analytical-Rational } & 1-2 years & 13 & 40.69 & 11.16 & & \\
Thinking & 3-5 years & 22 & 38.40 & 9.17 & 0.56 & 0.57 \\
& 6 years and over & 15 & 41.53 & 7.41 & & \\
\hline & Total & 50 & 39.94 & 9.18 & & \\
\hline \multirow{2}{*}{ Intuitive Thinking } & 1-2 years & 13 & 55.69 & 11.67 & & \\
& 3-5 years & 22 & 56.77 & 10.97 & 0.06 & 0.93 \\
& 6 years and over & 15 & 55.73 & 7.20 & & \\
\hline & Total & 50 & 56.18 & 10.00 & & \\
\hline
\end{tabular}

Table 4. Rational-Experiential Thinking Styles Scale as to Team and Individual Sports

\begin{tabular}{ccccccc}
\hline REI & Branch & $\mathbf{N}$ & $\overline{\mathbf{X}}$ & $\mathbf{S s}$ & $\mathbf{t}$ & $\mathbf{p}$ \\
\hline Analytical-Rational & Team Sport & 24 & 44.12 & 8.73 & \multirow{2}{*}{3.41} & \multirow{2}{*}{$0.001^{*}$} \\
\hline Thinking & Individual Sport & 26 & 36.07 & 7.91 & & \multirow{2}{*}{ Team Sport } \\
Intuitive Thinking & 24 & 52.16 & 9.12 & \multirow{2}{*}{-2.92} & \multirow{2}{*}{$0.005^{*}$} \\
\hline
\end{tabular}

\section{DISCUSSION AND CONCLUSION}

Within the scope of the research, the point average and standard deviation values of thinking styles in respect to the gender, being trainer of team or individual sports, coaching year and educational level were examined by a questionnaire which 30 male and 20 female, total 50, trainers coaching on different branches in the city centre of Elazığ answered.

Thinking style is a data processing approach which the individual puts to use on problem solving, perceiving the life and achieving his/her goals consciously or unconsciously. In this sense, "rational thinking" is described as a data processing manner which functions on conscious level separately from emotional effects which are preferential analytical and verbal and "intuitive-experiential thinking style" can be described as a data processing manner which the individual puts to use on data processing and is self-acting, associative, holistic and is not originally verbal and functions by being affected of momentary emotions [3].
The individual's productivity, adaptation and efficiency can rise by means of knowing which thinking style is being used densely, changing inefficient thinking styles to more functional ones in time and becoming skillful at being flexible on thinking styles as to the situations. [9]

It was tried to ascertain whether there was any differences between the level of thinking styles of male and female trainers concerning gender and thinking styles. However, it was found any differentiation at neither rational thinking nor intuitive thinking styles in terms of gender according to the analysis results. When the studies supporting our research were examined, it could not any statistically differences between gender and thinking styles on the studies conducted by Buluş (2000), Zhang (1999), Walter and his friends (1990), Duru (2002. These findings support our research.

When the analysis results in respect to the points of team and individual sport trainers' Rational-Experiential Thinking Styles on different branches were examined, it was found out that there was significant 
differentiation in terms of sub-scales of Rational Thinking and Intuitive Thinking factors. On the sub-scales of Rational Thinking; it was found out the point average of trainers on team sports was 44,12 and individual sports was 36,07. Significance level was observed as $p>0,001$. On the subscales of Intuitive Thinking; the point average of the trainers on team sports was 52,16 and individual sports was 59,88. Significance level was observed as $\mathrm{p}>0,005$. According to the research findings, it was figured out that the level of rational thinking "attending cognitive activities or not and enjoying cognitive activities or not" was higher on the trainers who coached at team sports. By contrast with, it was stated that the level of intuitive thinking "data processing and relying on his/her feelings and first impressions on daily life or not" was higher on the trainers who coached at individual sports. This study shows parallelism with Özmutlu and his friends' and Bernardo and his friends' studies $(7,2)$.

Within the context of the research, when the analysis results in respect to the points of Rational-Experiential Thinking Styles as to coaching year of trainers on different branches variable were examined, it was found out that there was not significant differentiation in terms of coaching year variable from the sub-scales of Rational Thinking and Intuitive Thinking factors. It can be figured out that there were not any differences on research findings because the group consisted of trainers, they attended many races before and got experienced and had low-anxiety. The studies conducted by Tümkaya, İflazoğlu, (2000), Tanrıkulu, (2002); Pulur and his friends (2012) support our research.

It was observed that the trainers' rational and intuitive thinking styles on different branches were at sufficient level. Cognitive processes such as thinking styles from the point of trainers and athletes have importance because it was thought that it would provide enlightening information on their choosing appropriate methods and techniques at sport environment.

\section{APPLICABLE REMARKS}

- It increases psychological performance coaches and athletes at the desired level.

- Studying this kind of different researches will be contributed to sports science.

\section{REFFRENCES}

1. Balgamis E., (2007). The Relationship Between Education Directors' Thinking Styles and Dealing Ways Behaviors Gaziosmanpaşa University Institute Of Social Sciences Department of Educational Science Department of Educational Management and Administration and Management Master's Thesis. Tokat

2. Sternberg, R.J. (1995.). In Search Of the Human Mind. Orlando, US: Harcourt Brace.

3. Sternberg, R.J., (1988). Mental Self Government: A Theory of Intellectual Styles and Their Development", Human Development, Vol.31, Pp.197-224.

4. Sternberg R.J. (1994.), Allowing For Thinking Styles,Educational Leadership,52,(3),36-40.

5. Sternberg R.J., (1997). Thinking Styles Combridge Unıversity Press, New York.

6. Coskuner Z., Gacar A., Yanlıç N, (2011). Evaluation of Physical Education and Sports Teacher Candidates' Thinking Styles. The Magazine of Sports and Performance Studies C: 3, S:1. Samsun

7. Epstein,S.; Rosemary, P. ; Denes , V.R and Harriet, H., (1996). Individual Differences in Intuitive Experiental and Analytical Rational Thinking Styles. Journal of Personlity and Social Psychology. Volume 63(4), 553-554.

8. Tanrıkulu, T.,(2002): Examination on Cognitive Structures (Automatic Negative Thoughts) and Problem-Solving Skills of Teenagers Who Grow Up at Orphanages and Who Live With Their Own Families, Marmara University, Master's Thesis,Istanbul.

9. Bernardo, A. B. I.; Zhang, L. F., and Callueng, C.M. (2002).Thinking styles and academic achievement among Filipino students. The Journal of Genetic Psychology, 163 2, 149- 163. 
10. Tekin M., Özmutlu İ., Erhan S. E., (2009). Examination on Decision-Making and Thinking Styles of the Students Who Enter Into Special Talent Examination. Atabesbd 2009; 11 (3): 42-56. Erzurum.

11. Tekin, M and Taşğın, Ö. (2009). Examination on Decision-Making and Thinking Styles of the Kickbox Trainers, Turkey Kickboxing Federation, Journal of Sports Sciences, Volume:2, Issue:1, pp:11-27

12. Bulus M. (2000). Examination of Attributional Complexity, Thinking Styles and Cognitive Consistency Preferences In Terms of Some Psychological Features and Academic Success, Unpublished Doctoral Dissertation Dokuz Eylül University The Institute of Educational Sciences. İzmir

13. Cacioppa, J., and R. Petty, Eds, Social Psychophysiology, New York: Guilford, 1982.

14. Palut, B. (2003). Examination of The First and Second Level Teachers' Thinking Styles on Personal and Teacher Role, Marmara University The Institute of Educational Sciences, Doctoral Dissertation, and İstanbul.

15.Zhang,L.F. (1999.). "Further Cross- Cultural Validation Of The Mental Self-Goverment" The Journal Ofpsychology.Volume 133, Pp.165/181.

16. Waters, L.K. and Zakrajsek. (1990). Correlates of Ne Ed for Cognition Total and Subscale Scores Educational and Psychological Measurement, Vol.50.

17. Duru, E. (2002). The Tendency on Helping-Behavior, Empathy and Thinking Styles Relationship On Teacher Candidates In the Context of Person-Case Approach and Examination Of This Variables In Terms of Some Psychosocial Variables Dokuz Eylül University The Instutite of Educational Sciences The Department of Psychological Services on Education Doctoral Dissertation. İzmir

18. Ozmutlu, I., Tekin, M. ve Arslanoglu, E. (2008). Examination of Ski Trainers' Decision-Making and Thinking Styles in Terms of Some Variables. I. World Judicial Sciences and Sports Congress, Gazi University Ankara

19. Tumkaya, S., Iflazoglu, A., (2000): "Examination of Automatic Thougts and Problem Solving Levels of Çukurova University Primary School Teaching Students In Respect of Some Socio-Demograhic Variables ," Cukurova University Social Sciences Journal, 6 (6), pp :43- 158.

20. Pulur A. et al. (2012). Examination of Problem-Solving Skills of High-Level University Athletes on Different Branches. Spormetre Physical Education and Sport Sciences Magazine, X (1) 1. 


\section{بروسى سبكهاى تفكر مربيان شاخههاى مختلف آتالاى كَاكار *، اوَّوزهان آلتونكَول، ايوض ناكار}

سبكهاى تفكر، موضوع انتخاب در استفاده افراد از توانايىهاى خود است. به عبارت ديكر، شامل فر آيندهايى است كه تعيين كننده نكرش ش افراد

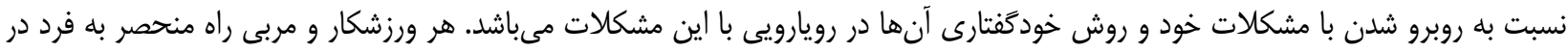

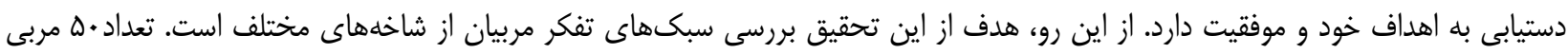

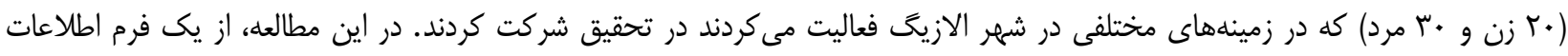

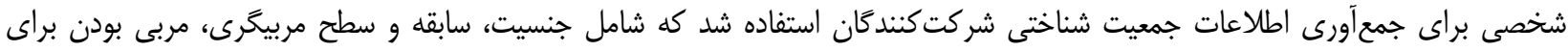

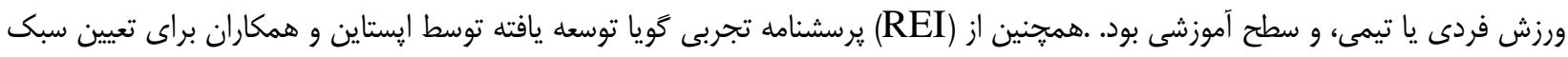

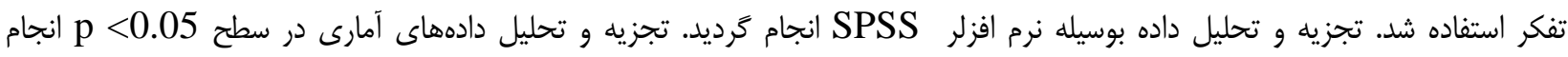

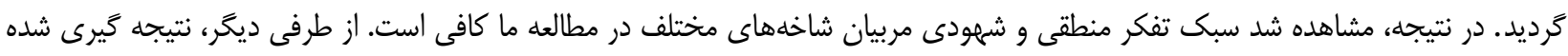

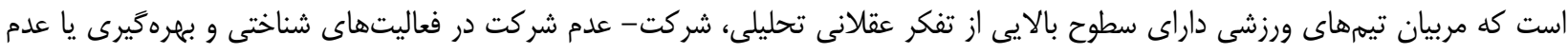

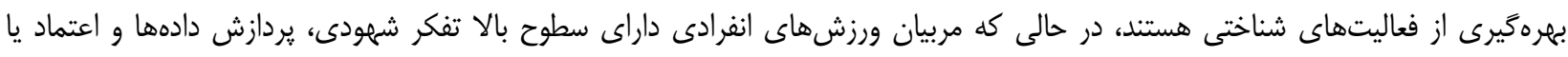

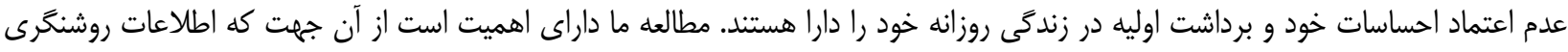

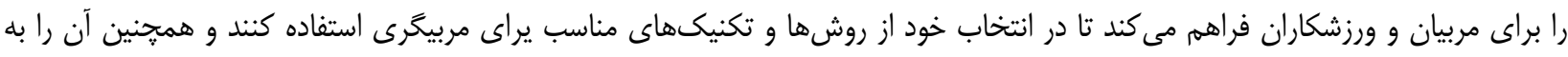

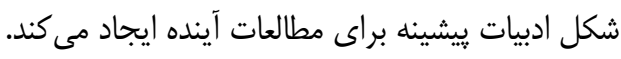

وازَّان كليدى: سبكهاى تفكر، مربيان، سبكهاى تفكر شهودى و منطقى. 
